\title{
NATURAL GAS AND BIOMETHANE IN THE EUROPEAN ROAD TRANSPORT: THE LATVIAN PERSPECTIVE
}

\author{
J. Savickis ${ }^{1}$, L. Zemite ${ }^{2}$, N. Zeltins ${ }^{2 *}$, I. Bode ${ }^{2}$, L. Jansons ${ }^{2}$ \\ 'ITERA Latvija \\ 50 Skanstes Str., Riga, LV-1013, LATVIA \\ ${ }^{2}$ Riga Technical University, \\ Faculty of Power and Electrical Engineering, Institute of Power Engineering \\ 12-1 Azenes Str., Riga, LV-1048, LATVIA \\ *e-mail: zeltinsh@edi.Iv
}

The European Union (hereafter - the EU) takes a strong position in the global fight against climate changes by setting ambitious targets on reduction of greenhouse gas (hereafter-GHG) emissions. A binding target is to reduce those emissions by at least $40 \%$ below 1990 levels till 2030, which would help make Europe the first climate neutral continent by the mid-21st century. Consequently, the expected 2050 emission reduction target for the EU is $80 \%-90 \%$ below 1990 levels. The EU's new economy decarbonisation framework - The European Green Deal - outlines and summarises Europe's ambition to become a world's first climate neutral continent by 2050 . This supposedly can be achieved by turning climate and environmental challenges into opportunities across all policy areas and making the energy transition just and inclusive for all.

The transport, and particularly road transport, is one of the most significant fossil fuel dependent segments of national economies across the EU. Oil dependency of all segments of the transport sector makes it the single biggest source of GHG emissions in the united Europe as well. Road transport is responsible for about $73 \%$ of total transport GHG emissions, as Europe's more than 308.3 million road vehicles are over $90 \%$ reliant on conventional types of oil-based fuels (diesel, gasoline etc.).

However, there is a wide range of low-emission alternative fuels for all kinds of transport that can reduce overall oil dependence of the EU's transport sector and significantly lower GHG in road transport. Among these alternatives a tandem of the natural gas and biomethane could be named as one of the most promising for short and mid-term transport decarbonisation solutions both in the EU and Latvia.

Keywords: biomethane, decarbonisation, natural gas, road transport 


\section{INTRODUCTION}

The EU takes a strong position in the global fight against climate changes by setting ambitious targets on reduction of GHG emissions. A binding target is to reduce those emissions by at least $40 \%$ below 1990 levels till 2030, which would help make Europe the first climate neutral continent by the mid- 21 st century. Consequently, the expected 2050 emission reduction target for the EU is $80 \%-90 \%$ below 1990 levels. This supposedly can be achieved by turning climate and environmental challenges into opportunities across all policy areas and making the energy transition just and inclu- sive for all. And sustainable mobility is given an important role in this process [1].

Road transport is one of the most significant fossil fuel dependent segments of national economies across the EU. Oil dependency of all segments of the transport sector makes it the single biggest source of GHG emissions in the united Europe as well. Road transport is responsible for about $73 \%$ of total transport GHG emissions, as Europe's more than 308.3 million road vehicles [2] are over $95 \%$ reliant on oil-based fuels [3].

Table 1. Road Vehicles by Fuel Types in the EU* (2018; \%)

\begin{tabular}{|l|c|c|c|c|c|c|}
\hline Type of Vehicle & Gasoline & Diesel & $\begin{array}{c}\text { Hybrid } \\
\text { Electric }\end{array}$ & Electric** & $\begin{array}{c}\text { CNG, LNG, } \\
\text { LPG }\end{array}$ & Other \\
\hline Passenger cars & 54 & 41.9 & 0.7 & 0.2 & 2.8 & 0.3 \\
\hline Light commercial vehicles & 7.1 & 91.2 & 0 & 0.3 & 1.3 & 0.1 \\
\hline $\begin{array}{l}\text { Medium and heavy } \\
\text { commercial vehicles }\end{array}$ & 1 & 98.3 & 0 & 0 & 0.4 & 0.2 \\
\hline Buses & 0.8 & 95.4 & 0.3 & 0.3 & 2.7 & 0.4 \\
\hline
\end{tabular}

* - including the United Kingdom

* - battery electric + plug-in hybrid

Source: ACEA Report Vehicles in use, Europe 2019

At the same time, there is a wide range of low emission alternative fuels for all kinds of vehicles available that can reduce overall oil dependence of the EU's transport sector and significantly lower GHG in road transport. The very term "alternative fuels" is universally undefined - some explanations emphasise the renewable energy component, while others, including Directive 2014/94/EU of the European Parliament and of the Council on the deployment of alternative fuels infrastructure (Directive 2014/94/EU), focus on all types and kinds of fuel more sustainable than traditional ones. Some other definitions even include coal-derived liquid fuels in a range of alter- natives. The following fuels are defined as alternative fuels in the U.S. by the Energy Policy Act of 1992: pure methanol, ethanol, and other alcohols, blends of $85 \%$ or more of alcohol with gasoline, natural gas and liquid fuels domestically produced from natural gas, propane, coal-derived liquid fuels, hydrogen, electricity, pure biodiesel, fuels other than alcohol derived from biological materials. In addition, the U.S. Department of Energy may designate other alternative fuels provided that they are substantially non-petroleum, yield significant energy security benefits, and offer substantial environmental benefits [4]-[5].

In the EU, however, according to Article 
2 (1) of Directive 2014/94 /EU, "alternative fuels" are sources of fuel or energy which at least partially replace fossil fuel oil sources in vehicle power supply and which have the potential to contribute to decarbonisation of transport and the environmental performance of the transport sector.

Directive 2014/94 / EU defines, inter alia, the following alternative fuels:

- electricity;

- hydrogen;

- liquid biofuels (biodiesel, bioethanol and hydrogenated vegetable oil);

- biomethane;

- compressed natural gas (CNG);

- liquefied natural gas (LNG) [6].

Among these alternatives a tandem of the natural gas and biomethane could be named as one of the most promising for short and mid-term transport decarbonisation solutions both in the EU and Latvia. Currently, transport represents only a minor consumer of the natural gas in the EU, amounting to less than $1 \%$ of its total demand. Despite an increase in registra- tions in recent years, alternatively powered passenger cars make up only about $3.7 \%$ of the total EU car fleet [2].

Transport accounts for around one third of overall energy consumption, and for achievement of Europe's climate neutrality by 2050 , a fundamental - $90 \%$ - reduction in transport emissions is needed [1]. It is also acknowledged that there will be no single solution for decarbonisation of this sector, with multiple alternative fuels being needed for different modes of transportation. Therefore, there is a potential for growth in demand for quite a few alternative fuel sources, such as natural gas, biomethane and other renewable gases (hereafter$\mathrm{RG}$ ), as well as electric mobility solutions, and in more distant future - blue and green hydrogen [1].

This research presents an analytic review of the growth dynamics of the natural gas mobility sector in the EU and Latvia with regard to possible trends of development of the natural gas and biomethane mobility in our country in next ten years and beyond.

\section{NATURAL GAS INFRASTRUCTURE AND VEHICLES}

Directive 2014/94/EU requires the EU Member States to ensure, by means of their national policy frameworks, that an appropriate number of recharging and refuelling points accessible to the public are put in place, first and foremost, targeting urban and suburban agglomerations, as well as the Core Trans-European Transport Network (hereafter - TEN-T). The alternative fuels that demand specific infrastructure solutions and for which Directive 2014/94/EU requires future targets from the EU Member States are electricity, CNG, LNG, and hydrogen [6].

As for $\mathrm{CNG}$ and $\mathrm{LNG}$, Directive
2014/94/EU prescribes that the Member States shall ensure that:

- an appropriate number of refuelling points for LNG accessible to the public are put in place by 31 December 2025, at least along the existing TEN-T Core Network, in order to ensure that LNG heavy duty motor vehicles can circulate throughout the Union, where there is demand, unless the costs are disproportionate to the benefits, including environmental benefits;

- an appropriate number of CNG refuelling points accessible to the public are put in place by 31 December 2020, in 
order to ensure, in line with the sixth indent of Article 3(1), that $\mathrm{CNG}$ motor vehicles can circulate in urban/suburban agglomerations and other densely populated areas, and, where appropriate, within networks determined by the Member States;

- an appropriate number of CNG refuelling points accessible to the public are put in place by 31 December 2025, at

(a)

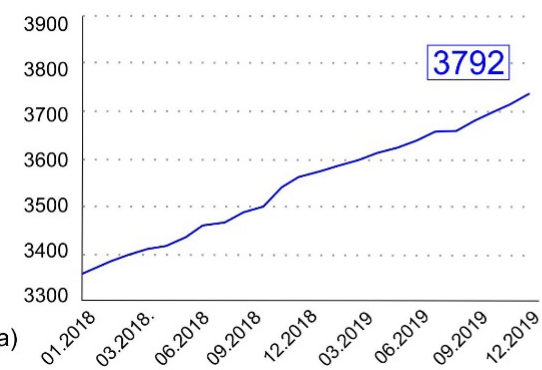

least along the existing TEN-T Core Network, to ensure that $\mathrm{CNG}$ motor vehicles can circulate throughout the Union [6].

Today, over 2 million natural gas vehicles (hereafter - NGVs) are in use all over the EU, where they are supported by a network of $4041 \mathrm{CNG}$ and LNG fuelling stations.

Fig. 1. Dynamics of the European CNG (a) and LNG (b) fuelling stations.

Source: NGVA Europe

CNG passenger cars make up about $0.4 \%$ of the vehicle fleet in the EU, but the largest market share of CNG by far $-4 \%$, is in Italy. In 2018, the breakdown of CNG vehicles in the EU was as shown in Table 2 , and further sector development in gen- eral followed the same trend. Significantly enough that CNG heavy duty vehicle registration was rather high in comparison with LNG heavy duty vehicle registration, which was 714 in 2018 [7], [10].

Table 2. EU CNG Fleet by Vehicle Type, 2018

\begin{tabular}{|l|l|l|}
\hline Vehicle Type & CNG Existing Fleet & New CNG Registrations \\
\hline Passenger Cars & 1.150 .000 & 65.835 \\
\hline Light Commercial Vehicles & 125.308 & 9914 \\
\hline Buses & 7901 & 430 \\
\hline Heavy Duty Vehicles & 14.163 & 514 \\
\hline
\end{tabular}

Source: NGVA Europe

NGVs are defined as all land-based motor vehicles, from two wheelers through to off-road. It includes original equipment manufacturers' vehicles, factory-approved conversions and post-sale conversions. Fuels used include CNG, LNG and biomethane or other RGs, which can be in gaseous or liquid form. Comprehensive statistics on NGVs is provided by NGV Global, which estimates that, in middle of 2019, there were around 27.7 million NGVs operating worldwide, with the biggest share close to 20 million, used in the Asia-Pacific region [8]. 


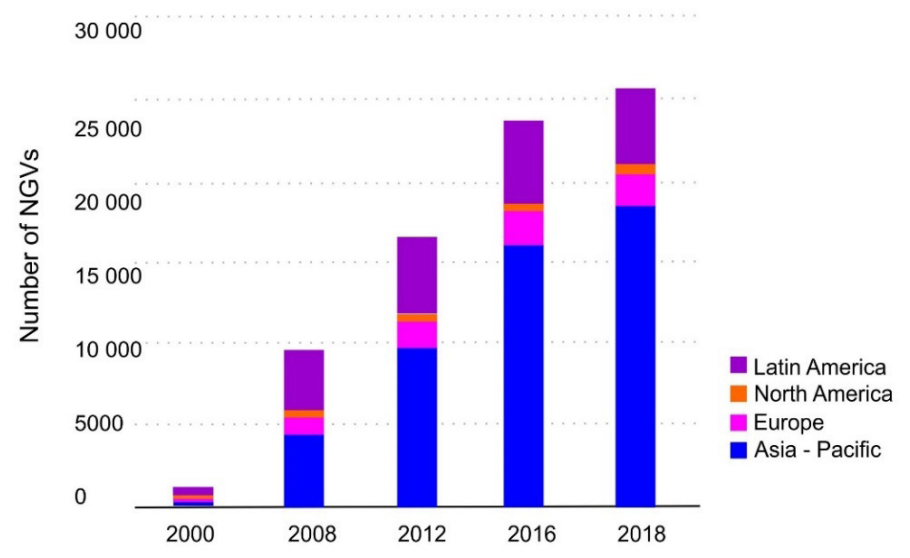

Fig. 2. Global NGV numbers by region, 2000 to 2018.

Source: NGV Global

Both NGV fleet and fuelling station networks are constantly expanding across Europe, too [9], even though currently it is quite challenging to estimate the rate and speed of development in the next few decades, as the European Commission's Summary on National Plans for Alternative Fuel Infrastructure clearly show significant differences in the Member States' political efforts to support CNG and LNG mobility. For instance, Germany already has a relatively dense network of $\mathrm{CNG}$ refuelling points, and available infrastructure could probably support more than five times the CNG vehicles on the roads in the country today. The German national policy framework defines a network of nine LNG refuelling points that could guarantee fulfilment of the maximum distance requirement for LNG refuelling points for heavy duty vehicles along the TEN-T Core Network. However, LNG driven heavy duty vehicles may have to deviate from the shortest route in order to refuel when travelling on the TEN-T Core Network [10]. At the same time other EU Member States, like Latvia and Lithuania, are still working on the very initiation of natural gas mobility and trying to find ways to trigger political support and financial incentives for expanding the pub- lic $\mathrm{CNG}$ filling station network.

Fuel logistics is one of the important points, which also defines future of the natural gas mobility. In the EU, CNG and LNG networks operate on different terms, as their fuel supply chain functions differently [11]. Traditionally, where natural gas distribution network is available, CNG fuelling is made available as well; thus, in locations, where natural gas network is absent, LNG fuelling is almost exclusive. However, availability of regional or national natural gas network is not the only option for development of CNG fuelling infrastructure. It could be installed in locations with local small-scale LNG fed natural gas networks as well. In terms of fuel logistics, availability of the natural gas grid for injection of biomethane is increasingly important [12]. In 2018, in the EU amount of biomethane injected into the grid was rather small - $2 \mathrm{BCM}$, in comparison with 363BCM of imported natural gas resources [13]. Biomethane can also be used in form of CNG as it is in many EU Member States. Biomethane is made available through local CNG filling facilities near biomethane plants. In many states, including Latvia, biomethane injection into regional or national gas transportation of distribution network still is not performed. 
In Germany, which is the EU's pioneer in biomethane injection into natural gas grids, in 2014 there were 168 biomethane plants with a total capacity of $204.000 \mathrm{~m}^{3} / \mathrm{h}$, but just a few of them were feeding biomethane into the grid. Currently, Germany has a strong biogas industry with more than 10,000 biogas plants, and it is also the EU leading country in terms of biomethane production [14]. In 2016, the amount of plants feeding the grid was 193 with 940 million $\mathrm{m}^{3}$ of biomethane fed into system, which contributed to about $1 \%$ of the natural gas consumption in Germany [12]. In 2018, however, 203 biogas plants with upgrading technologies were producing biomethane for natural gas grid injection needs. In total, biogas production was equal to about 10 billion $\mathrm{m}^{3}$ year, whereof biomethane plants produced 2.7 million $\mathrm{m}^{3} /$ day, or around the same amount of biomethane fed into the grid as two years ago [13].

The objective of Germany and France other country with clear future vision of centralised distribution of biomethane - is to replace $10 \%$ of their total natural gas consumption with biomethane via the natural gas grids by 2030, which is the most ambitious goal among the EU Member States. But, for the sake of clarity, it must be noted that in France, the legislation defines a target of $10 \%$ that should be represented by biomethane and other "green gases". However, the present stage of development of non-methane RG sector in the country allows only biomethane to be produced on an industrial scale to meet the demand set in the legislation [14].

\section{ROLE OF BIOMETHANE}

Biomethane is methane produced from biomass, landfill gases or gases acquired from different types of organic waste by means of purification of raw biogas, with chemical characteristics close or equal to natural gas. The initial product is raw biogas that is upgraded to reach a high methane content (usually $>96 \%$ ), which can then be used as a fuel for transport [15]. The number of biomethane production plants in the EU has nearly tripled between 2011 and 2017 , showing the fast development of this sector. By the end of 2017, there were 17,783 biogas plants and 540 biomethane plants in operation Europe-wide. The total installed electric capacity of biogas plants continued to increase in 2017, growing by $5 \%$ to reach a total of $10.532 \mathrm{MW}$. The electricity produced from biogas amounted to the European total of $65.179 \mathrm{GWh}$.

Biomethane production also increased, reaching about 1.94 billion cubic meters (BCM) in 2017 [16]. France had the highest growth rate for biomethane plants due to favourable policy conditions for biomethane production. The country is attempting to reach 1000 biomethane plants injecting its gas into the national gas grid by late 2020. To achieve this target, an incentive scheme has been put in place to support biomethane production. In 2017, 18 new biomethane plants were constructed in France and, before the end of 2018, 23 additional plants were installed, reaching a total of 67 biomethane plants.

The rate of increase in the number of European biomethane plants from 2016 to 2017 was half that between 2014 and 2015, but biomethane production nevertheless continued to grow, rising by $12 \%$ in 2017 . For biomethane as for biogas, there is a trend towards larger installations [16]. 


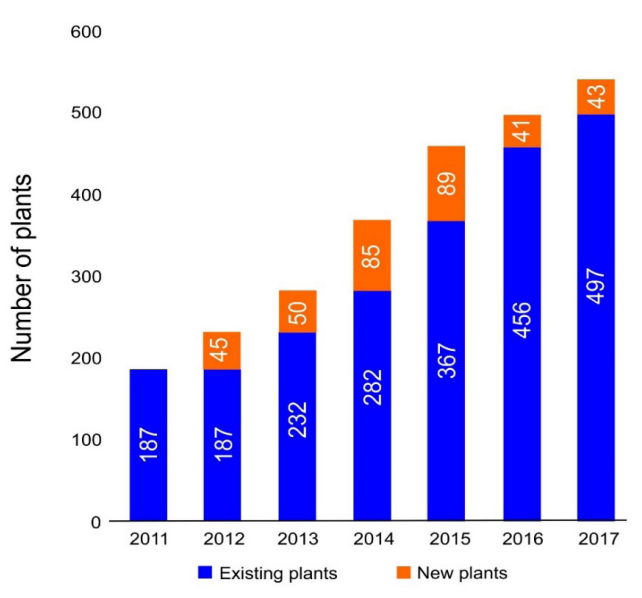

Fig. 3. Biomethane production plant in the EU (2011-2017).

Source: EBA Statistical Report 2018

The period between 2020 and 2030 will trigger the transformation of the natural gas industry to reduce its $\mathrm{CO}_{2}$ emissions, which currently represent $25 \%$ of the EU's total $\mathrm{CO}_{2}$ emissions and $20 \%$ of its power sector emissions. The production of biogas and its upgrade to biomethane is one of the best available options, alongside efforts to reduce methane leakage and gas flaring in the upstream part of the gas supply chain. In the longer perspective, it might be followed by green hydrogen produced from renewable electricity or blue hydrogen from gas combined with carbon capture and storage [13].

The biogas sector is expanding and has experienced many improvements in the past decade in terms of physical and economic efficiency. Germany still remains the European leader in biogas production, even though there has been little slowdown in recent years regarding the implementation of new biogas plants, mainly, due to changes in the national support scheme. On the other hand, the United Kingdom and France have continued to increase the number of new plants in operation, with possibility to overtake Germany in the next decade. Six countries - Austria, Germany, Italy, Portugal, Sweden as well as the United Kingdom - have currently achieved their biogas target for 2020 set in the National Renewable Energy Action Plans. Landfill and sewage gases account for around $24 \%$ of total biogas production, while most of the biogas comes from another source: anaerobic fermentation of agricultural feedstock. In Europe, up to $70 \%$ of the feedstocks used for biogas production come from the agricultural sector such as energy crops, manure, as well as agricultural residues. The utilisation of agricultural residues such as manure is particularly important in countries such as Denmark, France and Italy. This underlying growth in synergy between animal farming and biogas provides a profitable manure management solution. Energy crops are mainly grown and used in Germany and Austria. The municipal and industrial organic waste still has the potential to be developed for use in biogas production, but currently it is underrepresented [17].

Italy is the largest, but not the only EU Member State, that plans to develop a significant biomethane-based transport network around the existing CNG market. Sweden has also reported such an ambition. Even more, it has stated that $91.3 \%$ of its gas for vehicles came from renewable sources in 2018 , and $100 \%$ is likely to come in 2030 [18]. In addition, the Natural \& bio Gas Vehicle Association's (NGVA Europe) forecast shows that the potential of biomethane production in the EU would reach $45 \mathrm{BCM}$ by 2030 , where $19 \mathrm{BCM}$ would come from anaerobic digestion, 13 $\mathrm{BCM}$ - from synthetic methane from power to gas and $13 \mathrm{BCM}$ - from gasification. It is anticipated that $9 \mathrm{BCM}$ of this production would be used in transport [19].

However, other estimates show that the potential of biomethane production and, 
therefore, its abundance across all consumption sectors are limited, and, as it is shown in Fig. 4, there are just a few EU Member States that will have a higher esti- mated maximum potential of biomethane for all sectors of national economy in 2030 than the estimated percentage of transport energy needs.

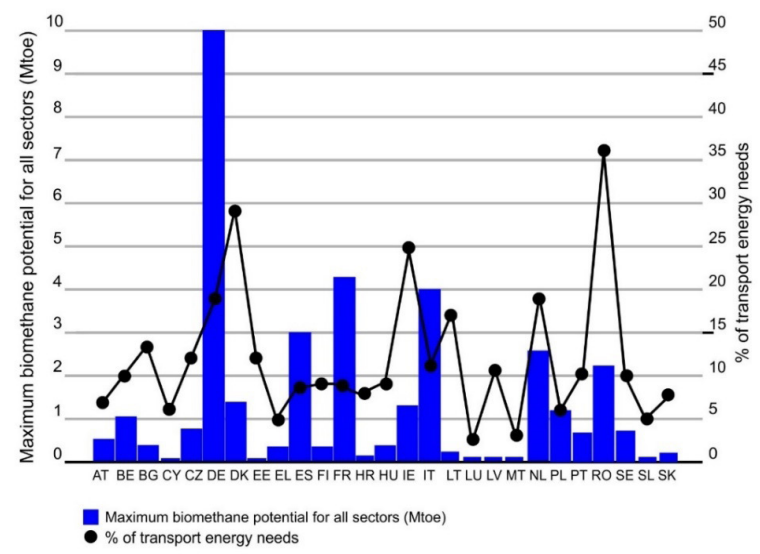

Fig. 4. Maximum biogas production potential by the EU Member States and the UK.

Source: Transport \& Environment citing data from CE Delft, 2016

One of the EU Member States, where the natural gas mobility sector is still emergingLatvia, also has to work at the development of methane use in transport. Currently, there are 59 biogas plants in operation there, and biomethane is mostly used for the production of electricity. However, according to present estimates, transformation of biogas into biomethane for use in transport would be regarded as a more cost-effective option in terms of economy than the combustion of biogas locally [20]. As seen in Fig. 5, the Latvian biogas plants are mostly located in a close vicinity of both natural gas transport and distribution networks, but injection of biogas into those networks is prevented by many private territories and other obstacles, which should be at least partially overcome in the near future.

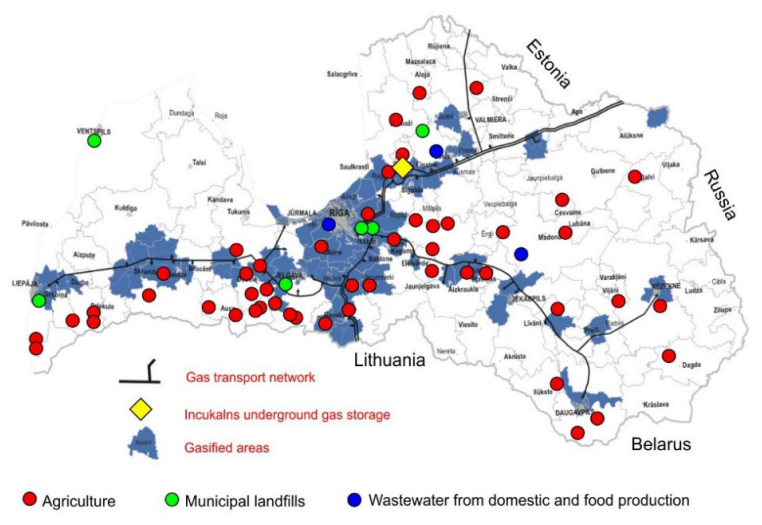

Fig. 5. Location and type of biogas plants in Latvia with respect to the natural gas network.

Source: JSC “Gaso", the Latvian Biogas Association 
Establishment of EU-wide quality rules for biomethane injected into the natural gas grids and used as transport fuel was one of the alternative fuel sector standardisation process priorities. Due to differences in existing Member States' legal acts and standards regarding the quality of biomethane for natural gas grid injection purposes, it was decided to prepare actual EU standard in two stages. The standardisation deals with biomethane as a common end product regardless of its production pathways or origin of the substrates.

Part 1 of standard EN 16723-2 "Natural gas and biomethane used in transport as well as biomethane injected into the natural gas network" was published in 2016, and it concerns the requirements of biomethane injected into the natural gas grids [21]. Part 2 , published in 2017 , specifies the requirements and test methods for natural gas, biomethane and blends of both for use as vehicle fuels (standardisation applies to these fuels irrespective of the storage state (compressed or liquefied)) [22].

The technical requirements and safety conditions for the use of biomethane-powered vehicles are identical to those for $\mathrm{CNG}$ vehicles, so also their use must be in compliance with regulations and standards, such as ISO 15403-1:2006(en) Natural gas Natural gas for use as a compressed fuel for vehicles - Part 1: Designation of the quality [23], [12].

At the national level, where access to the grid infrastructure is equal and nondiscriminatory, additional quality requirements have been set for biomethane and regasified LNG for injection into the natural gas grids (both transportation and distribution networks) [24].

In the long term perspective, injection of biomethane into the natural gas grid brings a valid option for decarbonisation of natural gas supply chain and provides local, renewable resources with wider market accessibility. Positive effects of biomethane injection into the natural gas grid include, but are not limited to:

- sustainable and effective use of biomethane, as using it on-site for electricity-only applications with no local demand for the heat energy would utilise only $30 \%-35 \%$ of available energy. Using biomethane in an efficient modern domestic boiler or remote modern CHPs, when it is transported through the natural gas grid, allows improving efficiency of biomethane up to $90 \%$;

- effective and widespread delivery of renewable heat, as biomethane injection into the natural gas grid enables renewable heat to reach over 444400 of homes in Latvia, where natural gas is physically available and could be used for heating purposes as well;

- active market participation, as the injection of biomethane into the natural gas grid gives producer direct access to a much larger market of potential clients than if biomethane was to be sold and used only locally. From the perspective of the biogas producer, injecting biomethane into the natural gas grid can, therefore, give access to a higher price than available locally. Depending on commercial factors, including the associated costs, this may mean a higher net price.

With correctly balanced incentives, biomethane is a commercially viable transport fuel as well: it can rely on existing natural gas infrastructure and contribute to reaching European climate targets in reduction of $\mathrm{CO}_{2}$ and other GHG emissions [17]. 
Transport sector in Latvia in 2018 accounted for $30.1 \%$ of the total final energy consumption and $78 \%$ of the total final consumption of oil products. More than $92 \%$ of Latvia's road vehicle fleet is made up of vehicles powered by traditional fuels. Alternative fuels - biofuels, biomethane, $\mathrm{CNG}$ and LNG - are used in only about $6 \%$ of all vehicles registered in Latvia. As for new passenger cars, between 2015 and 2017 the number of alternatively fuelled vehicles registered did not even reach $1 \%$.

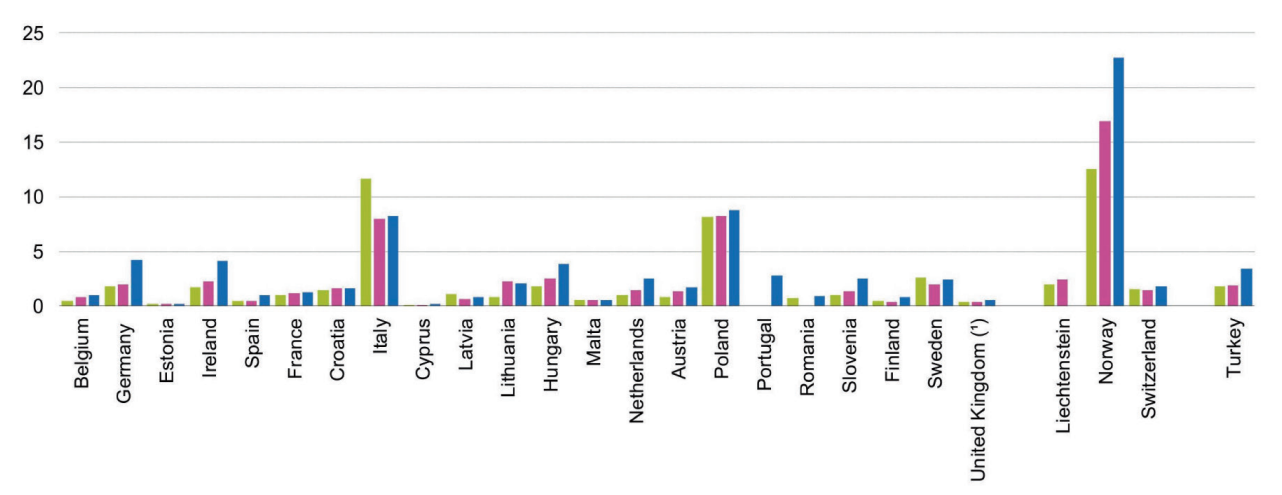

$=2015=2016=2017$

(') - Great Britain only; data on Bulgaria, the Czech Republic, Denmark, Greece, Slovakia not available

Fig. 6. New passenger cars with alternative fuel engines (2015-2017, \%).

Source: Eurostat

Almost all fuel used for transport is imported, except for a small share of biofuel. In 2018, road transport accounted for $82.6 \%$ of total transport energy, $11.9 \%$ for international air transport, $4.8 \%$ for rail, $0.5 \%$ for river and maritime transport, and the remaining $0.2 \%$ for inland air transport and energy used in pipeline transport. Transport accounted for $28.5 \%$ of GHG emissions [20].

In order to promote decarbonisation of the transport sector and reduce the negative environmental impact of its GHG emissions, as well as to transpose the requirements of Directive 2014/94/EU, “The Development Plan for Alternative Fuels 2017-2020" (hereafter - Plan) was adopted. Its aim was to identify the necessary trends of research and analysis that would lead to the development of further policies on the introduction of alternative fuels in certain transport sectors to ensure their sustainability. The task of the plan was to identify the current situation in the field of alternative fuels and to determine further steps for the introduction and promotion of alternative fuels in Latvia [25].

The plan requires, for example, that by 31 December 2020, at least five publicly available CNG filling stations be established in Latvia, and by 31 December 2019, a review of tax policy, including the level of excise duty on natural gas as transport fuel, be performed. Concerning the CNG filling station target, it is likely that this could be achieved as there are already two public 
CNG filling stations operating in Latvia and at least one more is planned to be opened in summer 2020. However, the agreement on the excise duty rate reduction for the natural gas as transport fuel has not been reached yet.

The excise duty on natural gas as transport fuel in Latvia is $99.6 \mathrm{EUR} / 1000 \mathrm{~m}^{3}$ [29], while excise duty on natural gas used for heating is $17.07 \mathrm{EUR} / 1000 \mathrm{~m}^{3}$. However, in 2019, as a result of negotiations between industry and policy makers, the Cabinet of Ministers of the Republic of Latvia drafted an order "Amendments to Cabinet Order No. 202 of 25 April 2017 "On Alternative Fuels Development Plan
2017-2020"', which, inter alia, provides an assessment of possible solutions to ensure the application of a reduction in excise duty on natural gas used as fuel in transport, if biomethane is added [20]. In the most optimistic case of the alternative fuel development in Latvia reflected in the plan, $\mathrm{CNG}$ and LNG combined would account for more than any other transport fuel in fleet, including diesel and gasoline, by 2050 , but for fulfilment of such a high ambition much stronger and politically coordinated support to RG industry, first and foremost domestic biomethane production and its end use both locally and by means of natural gas grid, must be provided.

Table 3. Possible Alternative Fuel Development in the Latvian Transport Sector (2025-2050, \%)

\begin{tabular}{|l|c|c|c|c|}
\hline Fuel & \multicolumn{3}{|c|}{ Year } \\
\hline & 2025 & 2030 & 2040 & 2050 \\
\hline Diesel & 67.2 & 64 & 34.4 & 23.1 \\
\hline Gasoline & 20.4 & 12.1 & 12.8 & 10.6 \\
\hline LPG & 7.1 & 13.9 & 7 & 6.4 \\
\hline LNG & 0.5 & 0.7 & 2 & 2.1 \\
\hline CNG & 2.5 & 4.5 & 19.9 & 30.2 \\
\hline Biodiesel & 0.2 & 0.2 & 10.4 & 12.9 \\
\hline Bioethanol & 0.7 & 0.4 & 0.5 & 0.4 \\
\hline Biomethane & 0 & 1 & 1.9 & 0 \\
\hline Hydrogen & 0 & 0 & 0 & 0 \\
\hline Electric cars & 1 & 2.5 & 10.2 & 13.2 \\
\hline Electric public transport & 0.5 & 0.6 & 0.9 & 1 \\
\hline
\end{tabular}

Latvia admits that the absence of a national policy plan has jeopardized the use of natural gas in transport. It has established targets for the deployment of $\mathrm{CNG}$ refuelling points accessible to the public. The targeted number of $\mathrm{CNG}$ refuelling points could support a significant increase in $\mathrm{CNG}$ vehicles. As indicated in the national policy framework, Latvia also has no plans for the deployment of LNG refuelling points in its ports [10].

As for the beginning of 2020, there were two public CNG filling stations, one closed filling station and three natural gas filling points available in Latvia. In our country, the current annual consumption of $\mathrm{CNG}$ is 0.2 million $\mathrm{m}^{3} / \mathrm{year}$, while in neighbouring Lithuania and Estonia - 13 and 14 million $\mathrm{m}^{3} /$ year, respectively. A study by the Ministry of Transport on the Development of Alternative Fuels concludes that natural gas, including $\mathrm{CNG}$, will be a transition fuel in a way to transport sector decarbonisation, so in next fifteen years, according to the most ambitious scenario of CNG filling station expansion along the Latvian natural 
gas distribution network, 172 CNG (69 of them along Core TEN-T network roads in 9 municipalities) and 6 LNG stations could be installed [25]. However, as Directive 2014/94/EU requires, distance between CNG filling stations in the TEN-T Core network should be $150 \mathrm{~km}$ maximum; it is highly likely that the actual number of CNG filling stations will be smaller.

Design and construction costs of CNG filling stations range from 100.000 EUR up to 300.000 EUR or even more, depending on the installed equipment and filling capacity. As the Estonian experience shows, a medium-sized station with a capacity of about 100-150 cars/day costs around 150.000 EUR to build [26].

In Latvia, CNG vehicles could potentially be suitable not only for private use, but also for taxi companies, freight transport, public buses and minibuses. In part, it could be appropriate for inland water transport and light-weight agricultural vehicles, too. Good stimulus for development of the domestic CNG mobility sector would be the addition of modern CNG-powered buses to public transportation fleets in cities, as it is already done in Jekabpils, with economic benefits of running $7 \mathrm{CNG}$ buses on the municipal lines $-35 \%$ in fuel costs alone [27]. For example, in the Nordic countries, including Sweden, the share of CNG buses in individual municipal bus fleets is as high as $80 \%$, while in Italy, the number of CNG public buses exceeds that of conventionally fuelled buses [28]. However, as there is no sufficient CNG filling station network established in Latvia yet, many companies, including large municipalities with their own public transportation companies, are choosing a more convenient alternative for the near future. It is expected, however, that the requirements of Directive 2014/94/EU and possible synergy between natural gas and biomethane in transport will facilitate faster growth of $\mathrm{CNG}$ sector in Latvia in next ten years, and, as a result, large car fleet owners will be made more aware of the potential benefits of transition to $\mathrm{CNG}$ as a traditional fuel alternative.

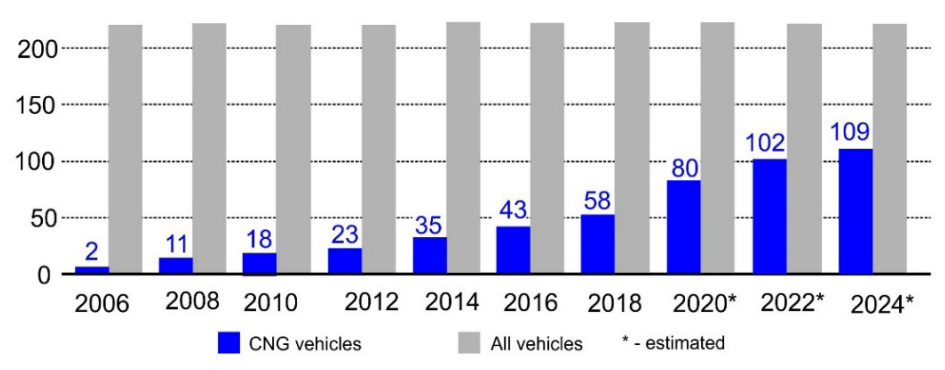

Fig. 7. Share of CNG vehicles in JSC "Gaso" car fleet.

Economic calculations for $59 \mathrm{CNG}$ cars currently used by the natural gas distribution system operator JSC "Gaso" (by 2024 it is estimated to reach 109) - the owner of Latvia's largest commercial CNG vehicle fleet dating back to 2006 - show that if the car travels about $12.000 \mathrm{~km} /$ year, CNG engine pays off in about 7 years, but if it has a mileage of $30.000 \mathrm{~km} / \mathrm{year}$, then the payback period decreases to $2-3$ years. Of course, each car manufacturer has its own models and the payback periods of $\mathrm{CNG}$ engines vary accordingly [9], [25]-[26].

However, given the current realities, it is expected that in the mid-term perspective oil-based fuels will remain the main source 
of transport energy in the EU and Latvia, although their importance will decrease already in the present decade. It is estimated that by 2030 oil resources and its products will still account for about $88 \%$ of the EU's transport sector energy needs compared to around $84 \%$ in 2050 [20]. Situation in the Latvian road transport sector will most likely follow the same trend with expected minor deviations, and there is a possibility that these deviations, with both political and industrial support, would bring long awaited growth and prosperity to one of the alternatives: natural gas - biomethane mobility.

\section{CONCLUSION}

The EU is about to significantly increase production and deployment of sustainable alternative transport fuels, as by 2025, about 1 million public recharging and refuelling stations will be needed for the 13 million alternatively fuelled low emission vehicles expected on European roads [1]. Transport should become drastically less polluting, especially in cities. A combination of measures should address emissions, urban congestion, and improved public transport. In addition, considerations regarding European emission trading for road transport are voiced, as a complement to existing and future $\mathrm{CO}_{2}$ emission performance standards for road vehicles. It includes natural gas and RG mobility as well, where many differences in the national policies of the EU Member States still exist. Further and more effective blending of $\mathrm{CNG}$ and $\mathrm{LNG}$, as well as biomethane into the European and Latvian road transport sector decarbonisation agenda is the only viable option foreseeable for overall gas mobility development in upcoming decades.

As for Latvia, the following conclusions on the matter could be drawn and recommendations presented:

- draft proposal of legislative regulation regarding development of the natural gas and RG mobility in Latvia should be drawn, focusing on a step-by-step strategy of road transport decarbonisa- tion by means of natural gas as a) transitional fuel, b) fuel that at once could be sustainably used together with other RG, mostly biomethane;

- revision of excise duty for the natural gas as transport fuel should be performed with at least $50 \%$ reduction of the duty for at least 5 years for natural gas and for undetermined period for biomethane (as biomethane is not currently used as the transport fuel in Latvia);

- extensive cross-sectoral study should be initiated and carried out in order to determine the actual stage of development of the Latvian biogas and biomethane production sectors with regard to investments into potential natural gas grid connections in locations of the highest and most effective biogas/biomethane production plant concentration with the most appropriate access to the natural gas transport and distribution grids;

- technical and economical case study should be proposed in order to establish technical options and financial investments needed for creation of a single natural gas injection point for one or several biogas plants (with estimated connecting infrastructure capital costs included and project financing breakdown presented); 
- technically sound and economically justified estimates should be made for evaluating the effectiveness of biomethane plant en masse connections to the natural gas grid with regard to mid-term development plans of grid operators' infrastructure;

- study should be initiated and carried out in order to establish the incentives that would be needed to reach the maximum percentage of NGVs in the Latvian road transport fleet by 2050 , and the measures to be taken in order to reach at least $1 \%$ of NGV in the Latvian road transport by 2025. Prospects regarding setting up CNG fuelling stations in the areas without coverage of natural gas grid could be examined with possibilities to couple local, LNG fed natural gas grids with public CNG fuelling station infrastructure.

\section{ACKNOWLEDGEMENTS}

The research has been supported by the National Research Programme, project "Trends, Challenges and Solutions of Latvian
Gas Infrastructure Development" (LAGAS) (No. VPP-EM-INFRA-2018/1-0003).

\section{REFERENCES}

1. COM (2019) 640 final. Communication from the Commission to the European Parliament, the European Council, the Council, the European Economic and Social Committee and the Committee of the Regions. The European Green Deal. [Online]. [Accessed: 1 April 2020] https://ec.europa. eu/info/sites/info/files/european-greendeal-communication-annex-roadmap_ en.pdf

2. European Automobile Manufacturers Association. (2018). Vehicles in Use. [Online]. [Accessed: 9 March 2020] https://www.acea.be/statistics/tag/category/ vehicles-in-use

3. Politico. (2017). Decarbonizing Europe's Transport Sector: On the Road to Low Emission Mobility. [Online]. [Accessed: 20 March 2020] http://erticonetwork.com/wpcontent/uploads/2017/01/DecarbonizingEuropes-transport-sector-on-the-road-tolow-emission-mobility-Draft-agenda.pdf

4. The U.S. Department of Energy. (n.d.). Alternative Fuels Data Center. Alternative Fuels Definition. [Online]. [Accessed: 29
February 2020] https://afdc.energy.gov/ laws/391

5. The Energy Policy Act. (1992). (102nd Congress H.R.776.ENR). [Online]. [Accessed: 17 February 2020] https://www. govinfo.gov/content/pkg/STATUTE-106/ pdf/STATUTE-106-Pg2776.pdf

6. Directive 2014/94/EU of the European Parliament and of the Council on the Deployment of Alternative Fuels Infrastructure. [Online]. [Accessed: 18 March 2020] https://eur-lex.europa.eu/ legal-content/EN/TXT/HTML/?uri=CELE $\mathrm{X}: 32014 \mathrm{~L} 0094 \&$ from $=\mathrm{EN}$

7. Fuel Strategies. (2019). Assessing $C N G$, $L N G$ and Biomethane. [Online]. [Accessed: 3 March 2020] http://futurefuelstrategies. com/wp-content/uploads/sites/7/2019/05/ MR_FOD_NG_Apr2019.pdf

8. The Natural Gas Vehicle Knowledge Base. (2019). NGV Global Current Natural Gas Vehicle Statistics. [Online]. [Accessed: 21 February 2020] http://www.iangv.org/ current-ngv-stats/ 
9. Natural \& bio Gas Vehicle Association. (2019). The NGVA Europe Vehicle Catalogue. [Online]. [Accessed: 1 April 2020] https://www.ngva.eu/medias/vehiclecatalogue-2019/

10. European Commission. (2017). Summary on National Plans for Alternative Fuel Infrastructure. [Online]. [Accessed: 1 March 2020] https://ec.europa.eu/transport/ sites/transport/files/2017-11-08-mobilitypackage-two/summary_of_national_ policy_frameworks_on_alternative_fuels. pdf

11. Psaraftis, H.N.(2015). Green Transportation Logistics: The Quest for Win-Win Solutions. Springer

12. Rogulska, M., Bukrejewski, P., \& Krasuska, E. (2018). Biomethane as Transport Fuel. [Online]. [Accessed: 30 March 2020] https://www.researchgate.net/publication/ 326376873_Biomethane_as_Transport_ Fuel

13. Eyl-Mazzega, M.-A., \& Mathieu, C. (2019). Biogas and Biomethane in Europe. Lessons from Denmark, Germany and Italy, Ifri: Etudes de L'Ifri.

14. Increasing Social Awareness and Acceptance of Biogas and Biomethane (2016). Report on the Biomethane Injection into National Gas Grid. [Online]. [Accessed: 15 March 2020] https://ec.europa.eu/research/participants/ documents/downloadPublic?documentIds= 080166e5abba7376\&appId=PPGMS

15. Koonaphapdeelert, S., Aggarangsi, P., \& Moran, J. (2020). Biomethane. Production and Applications. Springer: Singapore.

16. European Biogas Association (2018). European Biogas Association Statistical Report. [Online]. [Accessed: 18 March 2020] https://www.europeanbiogas.eu/wpcontent/uploads/2019/05/EBA_StatisticalReport-2018_AbrigedPublic_web.pdf

17. Bioenergy Europe. (2019). Statistical Report: Report Biogas. [Online]. [Accessed: 7 March 2020] https://bioenergyeurope.org/ article.html/103

18. NGV Global News. (2019). Natural Gas
Fuel in Sweden is 91\% Renewable. [Online]. [Accessed: 31 March 2020] https://www. ngvglobal.com/blog/natural-gas-fuel-insweden-is-91-renewable-0302

19. The Oxford Institute for Energy Studies. (2019). A Review of Prospects for Natural Gas as a Fuel in Road Transport. [Online]. [Accessed: 8 March 2020] https://www. oxfordenergy.org/wpcms/wp-content/ uploads/2019/04/A-review-of-prospectsfor-natural-gas-as-a-fuel-in-road-transportInsight-50.pdf

20. On Alternative Fuels Development Plan 2017-2020. [Online]. [Accessed: 28 March 2020] https://likumi.lv/ta/en/en/id/290393on-alternative-fuels-developmentplan-20172020

21. EN 16723-1:2016. Natural gas and biomethane for use in transport and biomethane for injection in the natural gas network-Part 1: Specifications for biomethane for injection in the natural gas network. [Online]. [Accessed: 20 March 2020] https://infostore.saiglobal.com/engb/Standards/EN-16723-1-2016-342125 SAIG_CEN_CEN_783563/

22. EN 16723-2:2017. Natural gas and biomethane for use in transport and biomethane for injection in the natural gas network-Part 2: Automotive fuel specifications.

23. Piskowska-Wasiak, J. (2016). Biomethane as a Transport Fuel. Technical Conditions for Use of Vehicles and Fuel Quality Requirements. NaftaGaz, 4, 271-278. DOI: 10.18668/NG.2016.04.06

24. MK noteikumi Nr. 650 "Prasības biometāna un gāzveida stāvoklī pārvērstas sašķidrinātās dabasgāzes ievadīšanai un transportēšanai dabasgāzes pārvades un sadales sistēmā". [Online]. [Accessed: 1 April 2020] https:// likumi.lv/ta/id/285189-prasibas-biometanaun-gazveida-stavokli - parverstassaskidrinatas-dabasgazes-ievadisanai-untransportesanai-dabasgazes-parvades-

25. Bode, I. (2019). Alternatīvās degvielas izmantošana (presentation). 
26. Gaso. (2018). CNG transporta un uzpildes infrastruktūras attīstības perspektīvas (presentation).

27. Ščerbickis, J. (2020). Jēkabpils veiksmes stāsts. 35\% ekonomija, izmantojot CNG autobusus (presentation).
28. Xylia, M., \& De Campos Silveira, S. (2015). Fuel options for public bus fleets in Sweden. Stockholm.

29. Latvijas Gāze. (2019). Vide rītdienai! (presentation). 